Review

\title{
Suggestion of experimental model on the innate kidney essence insufficiency syndrome for the development of humanitas traditional medicine
}

\author{
Byongjoo Lee ${ }^{1}$, Jihyun Go ${ }^{1}$, Duckgue Lee ${ }^{2, *}$ \\ ${ }^{1}$ Department of Pharmacology, College of Oriental Medicine, Kyung Hee University, Seoul, Republic of Korea; ${ }^{2}$ Department of \\ Cancer Preventive Material Development Research Center, College of Oriental Medicine, Kyung Hee University, Seoul, Republic of \\ Korea
}

\begin{abstract}
According to the traditional Korean medicine (TKM), kidney has been recognized as the roof of innate endowment because it plays an important role in the birth, growth, sexual reproduction, and aging. Kidney essence insufficiency syndrome (KEIS) is caused when kidney is impaired. KEIS is characterized by retarded development, decreased reproduction, tinnitus, loosening of teeth, and loss of hair and forgetfulness. In traditional Chinese medicine, KEIS mouse model was established by use of threatinjuring the kidney combined with over-fatigue. However, the TKM theory-based KEIS experiment model has not been described correctly. In the present study, we suggest a new KEIS experiment model including following cases; 1) weakness of father essence and mother blood, 2) life nurturing during pregnancy, 3) full-term gestation period.
\end{abstract}

Keywords kidney essence insufficiency syndrome, Korean traditional medicine theory, experimental model

\section{Role of kidney in traditional Korean medicine (TKM)} In TKM, the kidney is a viscera has a function leading to the development of sexual characteristics and being essential for reproduction. According to "Internal Classic, Plain Questions (內經, 素問) Chapter 1 (上古天眞論)” described as life of human being, kidney essence required of birth, growth, sexual reproduction, and aging. "Internal Classic, Plain Questions (內經，素問) Chapter 9 (六節藏象論)”, kidney plays the fundamental role of capturing and storing essences (腎者主蟄 封藏之本. 精之處也). Thus, kidney has been recognized as the root of innate endowment $(\mathrm{Ni}, 1995)$.

\section{Essence}

The essence is the most important part of life in human being. According to "Internal Classic, Miraculous Pivot (內經, 靈樞) Chapter 10 (經脈)", the essence is the fundamental substance that builds up the physical structure which is included by brain, marrow, bone, sinew, skin and hair (精成而腦膸生 骨爲幹 脈爲營 笳爲剛 肉爲牆 皮膚堅而毛髮長). And it maintains body function as prophylaxis, production of Qi. "Internal Classic, Plain Questions (內經，素問) Chapter 4 (金貫眞言論)", man who is full of essence has strong adaptability and has strong immune response. (故藏於精者 春不病溫 冬不藏精 春必病溫). “Internal Classic, Miraculous Pivot (內經, 靈樞) Chapter 10 (經脈)”and “Internal Classic, Miraculous Pivot (內經, 靈樞) Chapter 30 (決氣)” as human being is fertilized, it makes essence at first. (人始生先成精 兩神相搏 合而成形 常先身生是爲精). Therefore, according

\footnotetext{
*Correspondence: Duckgue Lee

E-mail: tomyoo27@gmail.com

Received August 16, 2013; Accepted August 25, 2013; Published August 31, 2013

doi: http://dx.doi.org/10.5667/tang.2013.0023

C)2013 by Association of Humanitas Medicine
}

to “Treasured Mirror of Eastern Medicine (東醫寶鑑), Essence (精門)", it is explained that the essence is the basis of innate (先天: processed from birth, relating to the natural endowment, in contrast to acquire after birth, the same as inborn)(精者 身之本也) (Huh, 1999).

Kidney essence insufficiency syndrome (KEIS)

Insufficiency of kidney essence is a pathological change of the kidney with insufficiency of its essence and impaired function (Who, 2007). It is caused by constitutional insufficiency (稟賦不足: congenital constitutional weakness as the main etiological factor of deficiency conditions), sexual overindulgence (房勞: exhaustion due to sexual overindulgence), aging, a long illness (久病). It marked by retarded development in children, premature senility, decreased reproductive function, tinnitus, loosening of teeth, loss of hair and forgetfulness in adults. Complications associated with these are as follows.

Kidney governs bone (腎主骨) / Kidney nourishes marrow (腎生膸)

According to "Internal Classic, Plain Questions (內經，素問) Chapter 23 (宣明五氣)” and “Internal Classic, Plain Questions (內經，素問) Chapter 10 (五藏生成論)”, the kidney governs bone(腎主骨，腎之合骨). Furthermore, it is explained that the kidney governs bone and bone marrow(腎主身之骨膸) in "Internal Classic, Plain Questions (內經，素問) Chapter 44 (瘘論)". So, when the kidney essence is enough, born and bone marrow are strong, but it is exhausted, they decreases, and it cause bone weakness.

Brain is the storage of marrow (腦爲䙃海)

According to "Internal Classic, Miraculous Pivot (內經，靈樞) 
Chapter 33 (海論)", brain is the storage of marrow, (腦者 髓之海)if the kidney essence were low level, bone marrow is lack and this situation gives feedback on brain, so man give a brain injury that corrupt human's memory.

\section{Tooth is other developmental part of bone (齒者骨之餘)}

According to "Treasured Mirror of Eastern Medicine (東醫寶鑑), Essence (精門)”, tooth is other developmental part of bone. Kidney takes charge of tooth's nutrition. (齒者 骨之餘 腎主營養), kidney essences makes tooth stronger.

\section{Kidney affects a role of grown hair (腎其華在髮)}

According to "Internal Classic, Plain Questions (內經, 素問) Chapter 9 (六節藏象論)”, kidney affects role of grown hair. (腎者 其華在髮), When kidney essence is full, hair growth is more and more. Also, it makes glossy hair. As "Internal Classic, Plain Questions (內經, 素問) Chapter 1 (上古天眞論)” is described detailed.

\section{Establishment of the innate KEIS (IKEIS) model}

As mentioned earlier, the kidney essence is closely related to birth, growth, aging, and death. Despite KEIS has cause of various disease, this experiment model of in vivo studies are insufficient. In Traditional Chinese Medicine, The kidneyessence insufficiency mouse model was established by use of threat-injuring the kidney combined with over-fatigue (Shen et al., 2011). But this model isn't described how KEIS explain the theory concerning TKM correctly. So, we make a hypothesis about innate KEIS (IKEIS) that followed by constitutional insufficiency. Based on the theory of TKM, constitutional insufficiency is caused by the following cases:

1. Weakness of father essence and mother blood

According to "Orthodox Manual of External Medicine (外 科正宗)”, fetus is formed and raised by father essence and mother blood (蓋身在胞胎, 皆賴父精母血, 借以生養) (Chen, 2007). It means that health of the parent is an important factor, determines health of the fetus.

2. Life nurturing during pregnancy

"Prenatal care during ten months of pregnancy(十月養胎 說)" is recorded in "Treatise on the Pathogenesis and Manifestations of All Diseases (諸病源候論)” (Ok et al., 2011). "Prenatal care during ten months of pregnancy" is one of the TKM theories about the normal development of the fetus and the attention point for pregnant woman's food, emotion, life style. It means that Life nurturing during pregnancy is another important factor, determines health of the fetus.

3. Full-term gestation period

According to "Peaceful Holy Benevolent Prescriptions (太 平聖惠方)”, the man who is born as mature infant or over due date is wealth and honor, on the other hand, the man, premature infant is poor and lowly (其中有延月而生者富貴而壽 有月 不足者貪賤而夭) (Wang, 1979). This means that full-term gestation "a pregnancy period" is one of the conditions, determine health of the fetus.

\section{Establishment of in vivo model}

Preterm birth (PTB < 37 weeks) is a major problem of pregnancy and continually interested in (Menon et al., 2011). According to previous study, PTB infants and children increased the risk of developmental delay that resulted in their underweight status and neurodevelopmental damage. Thus more social problems, less advanced cognitive functioning, more behavior problems, patterns of later growth, and higher prevalence of psychiatric disorders were found in preterm born infants, children and adults compared with full term peers (Brou et al., 2012). Its symptom shows similar with the symptom of IKEIS. For these reasons, we can infer the relation between IKEIS and PTB and suggest an experience model to study in vivo.

For the study of IKEIS, we selected mice model that were procreated in PTB. [A mouse model of spontaneous preterm birth based on the genetic ablation of biglycan and decorin] We render the hypothesis that PTB mice are different from normal birth mice when they act. For establishment of PTB mice model, we formulate that damage of parent's health affects IKEIS. We divide two groups that one group feeds normal chew, fresh water, and comfortable environment and another group feeds low fat diet, dirty water, and uncomfortable environment. If parent's condition is bad, second generation have IKEIS. Next, we study methods of active shock avoidance and Morris water maze. These methods were described previously. Briefly, in active shock avoidance, the apparatus consisted of a dark compartment $(40 \times 40 \times 40 \mathrm{~cm})$ connected via a small opening to an elevated, well-lit platform. Access from the platform to the dark compartment was regulated by a sliding door in the opening. The floor of the dark compartment was made of stainless steel bars, through which a scrambled foot shock could be delivered.

Two habituation trials were given on 2 consecutive days, 24 $\mathrm{h}$ apart. The first habituation trial (day 1) started with a 5 min adaptation to the dark compartment. Immediately afterward, mice were placed on the illuminated platform and allowed to enter the dark compartment. The sliding door was then closed, and mice stayed for another $3 \mathrm{~min}$ in the dark. During the second habituation trial (day 2), mice was placed directly on the illuminated platform. After entering the dark compartment the sliding door was closed. The animal was allowed to stay in the dark for 3 min once more. 24 later (day 3), the training trial was performed. The pre-shock entry latency was measured, and mice received two scrambled electric foot shocks $(0.6 \mathrm{~mA}$ a.c. for $3 \mathrm{~s}) 30 \mathrm{~s}$ apart, shortly after entering the dark compartment with the sliding door closed. Mice were removed from the dark compartment $30 \mathrm{~s}$ after the last foot shock. The HPSA group was Novelty and Cholinergic Signaling in SCN 509 also placed in the dark compartment for $30 \mathrm{~s}$ but did not receive a foot shock. 24 h (day 4) later, HPSA and TPSA groups were killed as described below, whereas the TEPSA group was placed on the platform to measure the post-shock entry latency to the dark compartment with a cutoff latency of $5 \mathrm{~min} .24 \mathrm{~h}$ later (day 5), these animals were killed. As such, HPSA and TPSA animals were killed $72 \mathrm{~h}$ and TEPSA animals $96 \mathrm{~h}$ after their first exposure to the test apparatus, but all experimental subjects were killed $24 \mathrm{~h}$ after their last exposure.

Active shock avoidance conditioning, a multi-trial associative learning task, was performed in a two-way shuttle box $(50 \times 26 \times 17 \mathrm{~cm})$. All experimental animals were habituated to the shuttle box for $5 \mathrm{~min}$. The sound of a buzzer served as the conditioned stimulus (CS), presented for $5 \mathrm{~s}$ prior to the onset of the unconditioned stimulus (US) of a scrambled electric foot shock $(0.3 \mathrm{~mA}$ a.c.) delivered through the grid floor of the shuttle box for $3 \mathrm{~s}$. When mice crossed the barrier within $5 \mathrm{~s}$ after the onset of the CS presentation, the CS was terminated immediately, no foot shock was applied, and the response was recorded as avoidance. If mice did not make avoidance, it either received the foot shock for $3 \mathrm{~s}$ or escaped from it during the $3 \mathrm{~s}$ delivery by crossing to the other side of the shuttle box. $8 \mathrm{~s}$ after the onset of the CS, both the CS and the US were terminated when a rat failed to make the response within that time. The animals received 60 trials in one daily 
session, with an inter-trial interval varying between 10 and $30 \mathrm{~s}$ (20 s on average).

In Morris water maze, the Morris water tank was made of molded white propylene, $70 \mathrm{~cm}$ in diameter and $20 \mathrm{~cm}$ high with one modification was rotated on a Dayton DC Parallel Shaft Permanent Magnet Gear Motor 12 RPM, 12 V electric motor at $11.4 \mathrm{~V}$. The motor at $11.4 \mathrm{~V}$ provided a speed of about $12.58 \mathrm{~cm} / \mathrm{s}$ for an object at a radius of $11 \mathrm{~cm}$, a speed similar to the average speed observed in a 4-arm water maze across a survey of mice. On the disk, holes 5.0, 11.0, 20.5, 27.0 and 30 $\mathrm{cm}$ from the center respectively, were drilled for the purpose of attaching the objects to be tracked. The tank was filled with water to a depth of $14 \mathrm{~cm}$, such that half of the object to be tracked was submerged, while the other half remained above water. These studies expect that PTB mice were lower ability to exercise than NB mice (Murray et al., 2010; Van der Zee et al., 2004).

\section{CONCLUSION}

Because KEIS is caused by a variety of reasons, such as constitutional insufficiency, sexual overindulgence, aging and a long illness, future research should focus on KEIS experiment model. So the study for KEIS experiment model by causing other factors except constitutional insufficiency is also required. Also there is a need to find specific biomarkers of KEIS that are distinguished with the control group, and to quantify them. Also the associations between constitutional insufficiency and IKEIS need to be studied in greater detail. It is necessary to study that how each case leading to constitutional insufficiency affects IKEIS.

\section{CONFLICT OF INTEREST}

The authors declare that there was no conflict of interest.

\section{REFERENCES}

Brou L, Almli LM, Pearce BD, Bhat G, Drobek CO, Menon R. Dysregulated biomarkers induce distinct pathways in preterm birth. BJOG. 2012;119:458-473.

Huh J. DongUiBoGam. (Seoul, republic of Korea: Bubin publishers co.), 1999.

Menon R, Torloni MR, Voltolini C, Torricelli M, Merialdi M, Betrán AP, Widmer M, Allen T, Davydova I, Khodjaeva Z, Thorsen P, Kacerovsky M, Tambor V, Massinen T, Nace J, Arora C. Biomarkers of Spontaneous Preterm Birth: An Overview of The Literature in the Last Four Decades. Reprod Sci. 2011;18:1046-1070.

Murray SA, Morgan JL, Kane C, Sharma Y, Heffner CS, Lake J, Donahue LR. Mouse gestation length Is genetically determined. PLos One. 2010;5:e12418.

Ni MS. The yellow emperor's classic of medicine: A New Translation of the Neijing Suwen with Commentary. (Boston, USA: Shambhala publications), 1995.

Ok JA, Park SH, Lee YT. Literature Study about Completion and Maintenance of Pregnancy. Kor J Ori Med Physiol Pathol.
2011;25:163-175.

SG Chen. Orthodox Manual of External Medicine. (Beijing, China: People's medical publishing house), 2007.

Shen SL, Su XJ, Wang YP, Wang WH, Shi JP, Yao JX, Qiang ZP. Effect of zibu shenjing fang (see text) on growth and development of the mouse with kidney-essence insufficiency and study on the mechanism. J Tradit Chin Med. 2011;31:232234.

Van der Zee EA, Biemans BA, Gerkema MP, Daan S. Habituation to a test apparatus during associative learning is sufficient to enhance muscarinic acetylcholine receptorimmunoreactivity in rat suprachiasmatic nucleus. J Neurosci Res. 2004;78:508-519.

Wang Huaiyin. Peaceful Holy Benevolent Prescriptions. (Seoul, republic of Korea: Hansung publisher co.), 1979.

World Health Organization. WHO international standard terminologies on traditional medicine in the western pacific region. (Geneva, Switzerland: WHO publications), 2007. 